Article

\title{
Territories of Extraction: Mapping Palimpsests of Appropriation
}

\author{
Berta Morata ${ }^{1, *}$, Chiara Cavalieri ${ }^{2}$, Agatino Rizzo ${ }^{1}$ and Andrea Luciani ${ }^{1}$ \\ ${ }^{1}$ Architecture Research Group, Luleå University of Technology, 97187 Luleå, Sweden; E-Mails: berta.morata@ltu.se (B.M.), \\ agatino.rizzo@Itu.se (A.R.), andrea.luciani@Itu.se (A.L.) \\ 2 Faculty of Architecture, Architectural Engineering and Urban Planning, UCLouvain, 1348 Louvain-la-Neuve, Belgium, \\ E-Mail: chiara.cavalieri@uclouvain.be \\ * Corresponding author
}

Submitted: 13 February 2020 | Accepted: 19 June 2020 | Published: 30 June 2020

\begin{abstract}
This article-framed as a methodological contribution and at the intersection between the critical urban, urban political ecology and world-ecology disciplines-builds on Corboz's metaphor of 'territory as a palimpsest' to explore the representation of the socio-economic and ecological processes underpinning uneven development under extractive capitalist urbanization. While the palimpsest approach has typically been used to map transformations of more traditional urban morphologies, this work focuses instead on remote extraction territories appropriated by the global economy and integral to planetary urbanization. The article suggests the central notion of 'palimpsests of appropriation' as a lens to map the extraction processes. It does so in its multi-scalar and temporal dimensions and on the basis of the three intertwined frames-i.e., the productive, distribution and mediation palimpsest-shortly exemplifying its use on the ground for the iron ore extraction territory in the Swedish-Norwegian Arctic. With this, the article contributes to the development of an expanded representational methodology and conception of territories of extraction-where social and natural production are brought together-illustrating how appropriation has been (re)shaping each of the frames throughout historical thresholds, but also how socio-natures are being (re)made in its image.
\end{abstract}

\section{Keywords}

appropriation; extraction; palimpsest; planetary urbanization; territory

Issue

This article is part of the issue "Territories in Time: Mapping Palimpsest Horizons" edited by Chiara Cavalieri (UCLouvain, Belgium) and Elena Cogato Lanza (EPFL, Switzerland).

(C) 2020 by the authors; licensee Cogitatio (Lisbon, Portugal). This article is licensed under a Creative Commons Attribution 4.0 International License (CC BY).

\section{Introduction}

The journalist and writer Po Tidholm opened his recent book Norrland with a poem from Albert Viksten written at the beginning of the 20th century, already reflecting on how the lands of northernmost Sweden had historically been robbed and its value been losti.e., as its riches have continuously been expropriated (forestry, hydropower, mining, railways and so forth) for the wealth and benefits of mainly state powers and capitalists (Tidholm, 2014). Tidholm's book, among other works, critically revises historical processes of uneven development within northern Sweden and Scandinavia (Figure 1). A process-like view very much akin to the lenses Henri Lefevre began developing from the very crucial moment when, in one of the many times in which he returned to his hometown in the Pyrenees, sulphur deposits had been discovered nearby-immediately leading to extraction, the building of a new town and the transformation of the landscape. Seeing such a process of how a predominantly rural landscape was being rapidly transformed into a predominant industrial urban landscape would then drive Lefebvre to start working on the transition of the rural to the urban-or what he called the process of urbanization (Elden, 2015), a work that would later lead him to the formulation of the radical hypothesis of the complete urbanization of society (Lefebvre, 1970). 


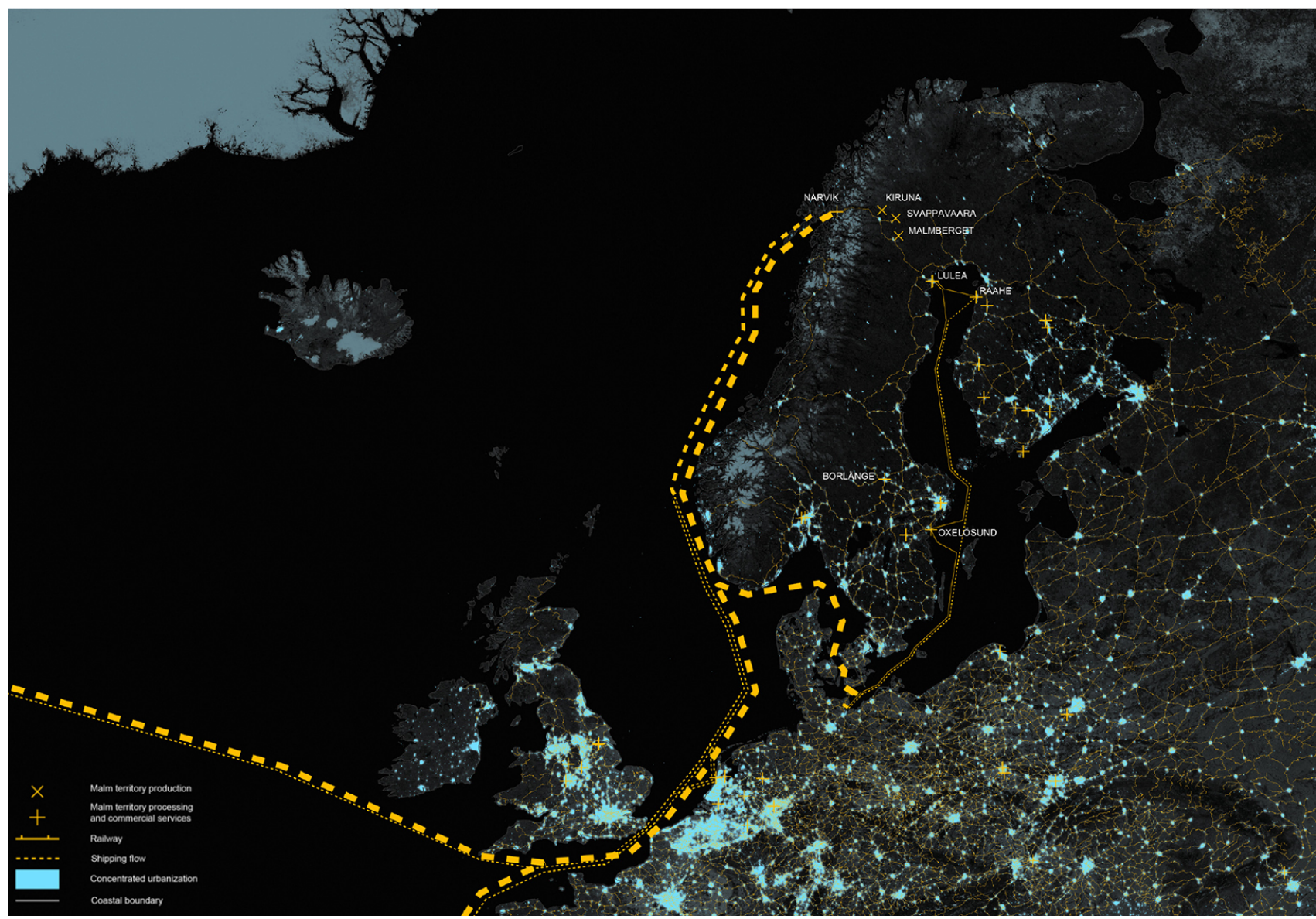

Figure 1. Scandinavia. Malm territory iron ore appropriated by global economy, railway, shipping flows, concentrated urbanization, mining production sites, processing and commercial services. Source: Elaborated by Berta Morata based on Geonorge, LKAB, Natural Earth, NOAA, SLU, SSAB.

This line of research has more recently been developed by the scholars of planetary urbanization (Brenner, 2019; Brenner \& Schmid, 2015), ever pushing forwardepistemologically and conceptually, but also methodologically and representationally-to critically explore the historical processes of urbanization from the most remote zones. These remote zones form territories of socalled 'extended urbanization,' that is, territories mostly of primary commodity production, circulation and waste disposal, commonly thought to lie outside the urban condition and critical to the material basis of planetary urbanization. One of these remote territories strongly linked to the extraction of iron ore is the 'Malm territory,' which has been forming since the mid-1500s across the sparsely populated and relatively isolated SwedishNorwegian Arctic and sub-Arctic region (located around the $66.5^{\circ}$ latitude), radically transformed over time into industrial-urban landscapes. Today, approximately $90 \%$ of Europe's iron ore is extracted from the mines in northern Sweden, where only the $0,0002 \%$ of its population live (LKAB, 2013). However, overall extraction in the region is not confined to mining alone, but historically deeply intertwined to forestry or energy: $97 \%$ of the forest under the alpine line-where no more trees can grow-is industrial in Norrbotten (Länsstyrelsen
Norrbotten, 2018); also, 30\% of Sweden's hydroelectric power is generated in Lule river alone, equal to $13 \%$ of Sweden's electricity (IVA Electricity Crossroads project, 2017).

Following this line of thinking and in the current conjuncture of climate change and environmental attention, territories of extraction such as the Malm territory need to be understood not only as occurring in the mines and remote regions far away from the main agglomerations; but as appropriation processes by the urbanization of society-and perhaps also (and in dialectic relation to) the urbanization of nature. Appropriation processes that are actually continuing across scales while simultaneously reproducing uneven spatial development patterns-and socio-nature inequalities. In this regard, there is an urgency to rethink territories of extraction and accordingly, this article proposes to tackle cartographic exploration via the proposing notion of 'palimpsest of appropriation.'

The article engages first with critical urban theory and expands it with literature from urban political ecology (UPE) and world-ecology, discussing around a specific set of analytical concepts and arguments. This positioning and building-up on key analytical dimensions then lead to a specific definition of 'appropriation.' Next 
in section three, the article explores the most relevant literature to the planetary urbanization framework on the representation of territories of extraction and discusses them conceptually and methodologically, to then revisit the palimpsest mapping methodology and the actual inherent possibilities that could be challenged from territories of extraction. In the fourth section, the notion of 'palimpsests of appropriation' is advanced and defined, and its methodology process deployed step by step, then using the Malm territory to shortly test the palimpsest of appropriation on the ground and discuss it analytically.

\section{Challenges From Territories of Extraction}

The planetary urbanization theoretical framework offers an important alternative lens to urbanization as a process-oriented approach-implicit in the Lefebvrian worldview-and one deeply embedded within the broader dynamics of capitalist development. Such processual understanding is central in this work and arguably helps to characterize the historical formation of territories of extraction in the age of capital, or 'Captialocene' (Brenner \& Katsikis, 2020; Moore, 2017, 2018). Yet it will be argued that, if moving beyond urbanization as mere geographical distribution, planetary urbanization could mobilise its framework to further challenge production. This would entail additionally complementing with UPE's and world-ecology, to then relate to the mode of production with a radically different approach - that is, making the shift of raising nature (the production of nature) to the level of space (the production of space) of Lefebvre (Smith, 2010).

\subsection{From Critical Urban Theory}

So far, and because planetary urbanization remains highly abstract, its conceptualization as the outcome of mutually constitutive processes of (1) concentrated urbanization, (2) extended urbanization and (3) differential urbanization, cannot be used directly as sole analytical dimensions for the analysis of contextual specificities. The latter appear as key if used linked to the changes unfolding on the ground through the use of other mediating concepts beyond planetary urbanization (Brenner \& Schmid, 2015; Khan \& Karak, 2018). Concentrated urbanization (1) is broadly conceived concerning "the density of population and its asymmetric distribution," or to "the distribution of built space in the form of structures and infrastructures" (Brenner \& Schmid, 2015). Though, concerning territories of extraction, it refers to landscapes with high levels of primary production, in the form of for example, extraction of minerals. Therefore, mining operations-due to the high concentration of activity in certain geologically dense composition areas-can be both very punctual (like most drilling operations), or very land extensive (like open pits; Katsikis, 2016). Extended urbanization (2) refers to the outward expansion of the urban form from the city centres or 'agglomeration landscapes,' encompassing both infrastructures and landscapes of primary commodity production or 'operational landscapes.' More significantly, and to constantly overcome sociospatial barriers for capital accumulation, the forms of extended urbanization often lead to the expropriation, privatization, and profit-oriented modes of appropriation of land and water-i.e., as by large-scale infrastructures (mines, dams, industrial corridors) in remote regions which end up displacing populations, indigenous peoples and everyday social spaces-while disrupting established forms of livelihood. In this line, the theoretical framing of operational landscapes of extended urbanization as merely a mode of geographical organization can be troubling-framed as they are as deriving from a direct relation to 'agglomeration economies' (from economic geography). The latter has been distinguishing between three categories-localization, industrialization and urbanization economies - and translated in the form of so-called 'landscapes of possible externalities.' Yet, if moving beyond the externalities form-which is limiting and characterizing operational landscapes by some sort of 'machinic' behaviour to the elements of natural geography-planetary urbanization could challenge production beyond its socio-spatial understanding, or say, as mere configurations of particular geographicallydistributed elements.

To this extent, and in line with the processual understanding of the urban, the third intertwined moment of differential urbanization (3)-between the forms of extended and concentrated urbanization-implies a creative destruction process of socio-spatial configurations concerning the broader dynamics and crisis-tendencies of capitalism. This moment highlights the perpetual dynamism of capitalist forms of urbanization-both concentrated and extended-in which socio-spatial configurations are tendentially established, only to be rendered obsolete and superseded through the relentless forward motion of the accumulation process and industrial development (Brenner \& Schmid, 2015). Yet, in each urbanization cycle differentiated geographies carry transformative potentials in the social, economic and cultural spheres (and perhaps also the natural). In this regard, differential urbanization could be key to the purpose of bridging the advancements of planetary urbanization in its socio-spatial configurations on the reproduction of the social relations of production, and other disciplines' complementing insights.

\subsection{From UPE and World Ecology}

Considerably, planetary urbanization could expand its framework by engaging with the latest UPE advancements on moving beyond the urbanization of nature. Acknowledging socio-natures as being increasingly enrolled in the circuits of capital beyond city/no city, and so, further challenge the mode of production from territories of extraction (i.e., the ways of organizing socio- 
natures under capitalism). That is to say, considering the post-cityist UPE of linking the tracing of metabolic exchanges of matter, energy and capital not only as unidirectional processes concerning cities, but to the extended forms of urbanization key to uneven geographical development (Angelo \& Wachsmuth, 2015; Arboleda, 2016; Katsikis \& Ibañez, 2014; Tzaninis, Mandler, Kaika, \& Keil, 2020). Thereby the heart of the matter may lie not in the mere quantification of flows (as not all are valued within capital's dynamism); but more in line to the worldecology optic, into the articulation of social and natural forms-moving beyond the 'Cartesian' binary and dualisms. In this light, the operational landscapes of extended urbanisation could be characterized not merely by a machinic behaviour whereby capitalism is developing and acting on nature; but as active landscapes continuously transformed by the articulation of a whole set of relations-of capital (accumulation), (pursuit of) power and what is more (the production of) nature-that are not fully under the control of economic and political actors, and where capitalism develops through the web of life (Moore, 2015b, 2016).

This set of relations has been reflected in depth by Jason Moore with the concept of 'ecological surplus' and its tendency to fall between 'capitalization' and 'appropriation.' Where capitalism not only extracts value through the exploitation of paid work but also, and crucially, from unpaid work by both human nature and nature alike (i.e., like geological processes that produce minerals or the water cycle for hydropower energy generation). It is precisely on this appropriation of unpaid work or the socalled "free gifts of nature" by Marx (Marx \& Mandel, 1976), that the production-process relation is to be critically questioned. Briefly, the ecological surplus can be defined as "the ratio between the actual capital investment paid work (wage-labour), fixed capital and raw materials; and the unpaid work that is mobilized with it" (Moore, 2015a). In its tendency to decline, the ecological surplus is offering a core additional layer for the historical analysis here intended: for exploring the relations of power and re/production whilst bundled with the specific historical natures in territories of extraction, for exploring its particular ways of organising the society-nature relations and more notably in the creative-destruction moments of crisis throughout the successive eras of accumulation. Across these moments, the ecological surplus can be: in underproduction, very high, eroding, contracting and in conjuncture (Moore, 2015b). Historically, in its tendency to decline, the ecological surplus is linked on the ground with new (not just sociospatial but) socio-nature forms of differential urbanization-a dialectic that is importantly including the production of nature relation.

For example, within a previously 'untouched' mining deposit or uncommodified 'first nature,' minimal investment in labour and machinery might be needed to exploit high amounts of work that have been produced by nature in the deep time of its geological formation. As accumulation proceeds, the initial high ratio of ecolog- ical surplus tends to fall, the exhaustion of the resource and closing of frontiers bring about expansion, intensification, technological innovation and processes of creative destruction-a commodification of socio-nature relations. A 'second nature' is then produced, which in turn depends upon maximized throughput or say, upon further appropriation of raw material outputs to be generated by smaller inputs of capital and capitalist power (i.e., as unpaid rights for mining into a colonized territory). And yet with time, a new frontier opens up: the 'financialization of nature,' involving a new vertical integration of nature that moves beyond appropriating available nature to rather produce an inherent social nature as a basis of new sectors of production and accumulation (Smith, 2007). The production of nature is thus an important aspect historically characterizing extended urbanization, deeply intertwined with the notion of differential urbanization and successive expropriations, violence and dispossession practices. This process involves economic forces, yet is strongly dependent on the stateto seize portions of the earth through extra-economic force-and ruled by science-to objectify the social and natural world as a means to exert direct control in service to commodity exchange.

Thus, the key notion of appropriation in this work is to be understood as within the mentioned logics of separation located at the core of 'primitive accumulation,' allowing for unpaid work/energy to be mobilised for capital accumulation. At its root, according to Marx, the capital relation presupposes the separation of the workers from the means-land and water-that would allow them to be self-sufficient (Marx \& Mandel, 1976); it is a process of expropriation premised on violence and created by the same capital relation-highly visible in territories of extraction and extremely on indigenous lands and waters. However, primitive accumulation here is to be understood not just as part of an original past but more in line with what new readings propose, as a historically ongoing dynamic where appropriation goes far beyond the geographical expansion of capital. This is particularly true with the shift of finance and the real subsumption of nature to capital, historically enabling capital to transcend geological and temporal limits towards accumulation. What is more, technological change is allowing for the continuous production of 'an outside' but within the same physical boundaries, advancing not merely by appropriating socio-natures but by (re)making them for capital to work harder and faster (Arboleda, 2020). As such, the limits to this relational process of appropriation are not reduced to biophysical realities alone but located between the capitalization of nature and the ecological surplus at its highest point (Moore, 2015b). Indeed, the limits have a particular way of organizing (articulating) humanity's relation to nature, in short, of changing co-produced socio-nature relations between the agglomerated and operational landscapes.

Under this framework and linking back with the processual approach to the urban, territory is also 
to be thought of as a process and not as an outcome. Continuously made and remade by states, science and corporations, territory becomes a form of political technology (Elden, 2019; Mezzadra \& Neilson, 2013). Extraction is also to be understood as processes, going far beyond the merely forced removal of raw materials to supply significant cities and zones of the world, and becoming historically intermingled with finance, logistics and urbanization (Arboleda, 2020; Gago \& Mezzadra, 2017; Mezzadra \& Neilson, 2017). Furthermore, to be able to expropriate large and varied geographies, states require forceful financial penetration on the land to be mapped-in the first moment of surface expansion - and mobilized-for its steady intensification in volume. It is in this sense that the map becomes not only the territory but the technology (Bélanger \& Lister, 2018). The critical representation through time and scales of these extraction processes can thus provide important analytical insights for elucidating the uneven role of appropriationboth in the surface and in volume-across the successive historical ecological crisis under the capitalist mode of production.

\section{Images of Extractive Territories}

The next paragraphs review the literature on the representation of extraction territories by exploring the two basic interpretations of the concept of territory as signalled of more importance to the analytical framework of planetary urbanization: (1) the operational landscape approach, prevailing mainly in the Englishspeaking world and more recently developed as from the 2010s, and (2) the morphology approach, emerging from the French and Italian-speaking worlds, antecedent from the 1980s (Schmid, 2015).

In line with the (1) operational landscape approach, the research in the fields of urbanism and landscape has lately gained interest for territories of extraction, and the latter has been the object of plural descriptions and representations (Bhatia \& Casper, 2013; Brenner et al., 2013; Correa, 2016; Ponte \& Kowal, 2017; Sordi, Valenzuela, \& Vera, 2017). As a result, these spaces have progressively been defined as regions located far beyond the city centres but paradoxically providing resources and goods for cities so they can develop and operate (Brenner \& Katsikis, 2020). For that, several layers of connectivity infrastructures have been continuously deployed and driven resource extraction to ever faster and more remote areas. Settlements have in turn been put in place and are often referred to as 'camps' or temporary living hubs, that is, as part of the overall extraction industry and infrastructure (Correa, 2016; Sordi et al., 2017). Operational landscapes thus often reflect a particular layout and socio-economic plan of extended-but also a certain degree of concentrated-urbanization of extraction, a form of urbanization in dialectic relation to the elsewhere agglomerated landscapes it supplies. More critically, in the book Empire Extraction (Bélanger
\& Lister, 2018), the notion of territory is used to signal the power dimension and political control of the State on the land-the geographical surfaces that the State maps as its political territory-while exercising cultural domination, indigenous dispossession, settlement imposition, resource acquisition, environmental engineering or international disposition. In this sense, the 'state' map is here not only the territory but also the technology through which the power of the State is continuously upheld. Together, through both power and mapping, the State is severely considered the preeminent extractive technology (Bélanger \& Lister, 2018). Therefore, within these English-speaking world interpretations, territory is regarded as a political entity, a demarcated abstract space or as a large area equating to the extent of an authority. Extraction and the enabled appropriation are dematerialized: territory, when defined as a bounded portion of the earth's surface, with a conceptualization of land as a passive container, is giving a troubling-and it will be argued uneven-role of nature in urbanization processes.

A fundamentally different position is prevailing in the (2) approach as morphology, where both morphology and territorial materiality are taken as a starting point. What emerges here is that territory is produced by human activity, be it either material or mental. In this line, Claude Raffestin, geographer in Geneva, referred to territory as the outcome of social conditions, relations and power structures (Raffestin, 1980). Similarly, Corboz (1983) would regard territory as a product of historical processes of transformation, putting forward the metaphor of the 'palimpsest' and understanding the land as constantly reworked through the variety of social and economic processes (Corboz, 1983a). For both authors, it is clear that territory is a socially appropriated space. However, conceptualizing the land as remote, bounded and being merely and constantly socially reworked is perhaps further enabling the dualist visions between society and nature, between the city and the landscapes of extraction, or say, between production and distribution infrastructures. This work takes on this critique and uses the aforementioned analytical dimension of the ecological surplus to explore the representation of the asymmetrical processes, between the hidden appropriation (of unpaid work) and the concerning capitalization (the exploitation of labour productivity). Thus understanding how socio-natures are co-producing each other, and how production and distribution are just different 'moments' of the same historical process (Marx \& Nicolaus, 1993).

\section{Mapping Palimpsests of Appropriation}

The palimpsest metaphor applied to territory is still a very productive methodological tool which can be further mobilised and challenged when brought to territories of extraction. Beyond Corboz's recognition of the land as being formed by separated and yet mutually influenced layers of natural and human-induced pro- 
cesses, recent revisitings on the palimpsest focusing on ecocritical discourses have moved forward to consider them as merged via time (Layne, 2014). In effect, by allowing the multiple layers to acquire the same importance, the palimpsest can transcend dualisms and render visible the hidden intertwined historical transformations. However, approaching the territory as a palimpsest has some limitations, it can project visions (past and future) but cannot add that which never was (Layne, 2014). Also, it's very representation depends on subjective operations done with a certain "margin of interpretation" by the researcher (Genève République et Canton, 1993). And, as Corboz worried, landscapes cannot be reduced to maps-which have the potential to filter out cultural aspects such as seasons, experiences or memories (Corboz, 1983).

The idea of 'palimpsest of appropriation' is proposed here as the metaphor through which to render visible the hidden historical processes of appropriation of unpaid work (from both human-nature and nature alike) fundamental to the dynamics of accumulation in territories of extraction and intrinsic to capitalist urbanization. For that purpose, this article engages with the theorization of the circulation of capital-as laid out by Marx in the second volume of Capital, extensively interpreted by Harvey and recently more specifically into extraction by Arboleda (2019; see also Harvey, 1989; Marx \& Mandel, 1992)-and uses it to spatialize and map appropriation processes through time and scales. On this basis, it proposes to deploy the mapping operations into the three intertwined frames (different moments of the same process) where capitalist appropria- tion takes distinct intricate spatial configurations: (1) production, which comprises both the built and non-built environment, directly or indirectly involved in the iron ore production-pits, shafts, tales, processing facilities, industrial buildings, plots, housing for the workers, public facilities; (2) distribution, formed by all the network infrastructures that enable the transportation of iron ore from sites of extraction to their exchange in the marketports, railway, roads, paths, cableways, fiber cable, energy grid; and (3) mediation, which encloses the financial actors and institutional systems investing in science and technology (harnessing science to production to contribute to the processes that continuously revolutionize the productive forces in society), and in social expenditures (for the necessary reproduction of labour power, their qualitative improvement and integration and even repression of the labour force)-constantly mediating and transforming extraction at multiple spatial scales.

The combination of the three frames forms a matrix (Table 1), providing a framework of interpretation that sheds light on the modes in which extraction territories have been continuously appropriated and reshaped into different uneven spatial socio-nature configurations. Yet, the process for mapping the three frames can be described according to three-sometimes overlapping-mapping operations or gazes that mainly correspond to (1) the elementary, (2) the inter-scalar and (3) the chronological.

The elementary gaze (1) is recognising the elements that produced such processes and proceeds to break down their mapping complexity into clear individual parts, that is to say, a process of description (Cavalieri

Table 1. Table matrix palimpsest of appropriation.

\begin{tabular}{|c|c|c|c|}
\hline & Production & Distribution & Mediation \\
\hline \multirow[b]{2}{*}{ elementary } & layers & layers & texts \\
\hline & $\begin{array}{l}\text { (water, herding routes, roads, } \\
\text { harbours, geology, orography, } \\
\text { vegetation, housing buildings, } \\
\text { other public facilities, } \\
\text { production buildings, plots } \\
\text { and land use) }\end{array}$ & $\begin{array}{l}\text { (water, sameby, railway, paths, } \\
\text { electricity network, shipping } \\
\text { routes, cableways) }\end{array}$ & $\begin{array}{l}\text { (key historical facts, financial } \\
\text { actors, institutions, policy } \\
\text { frameworks) }\end{array}$ \\
\hline \multirow{13}{*}{$\begin{array}{c}\text { inter-scalar } \\
+ \\
\text { chronological }\end{array}$} & plot $1: 2,500$ & plot $1: 2,500$ & plot \\
\hline & settlement $1: 5,000$ & settlement $1: 5,000$ & settlement \\
\hline & regional 1:500,000 & regional 1:500,000 & regional \\
\hline & national $1: 10,000,000$ & national $1: 10,000,000$ & national \\
\hline & global 1:20,000,000 & global 1:20,000,000 & global \\
\hline & synchronic & synchronic & synchronic \\
\hline & (a) 1550-1888 | in & (a) $1550-1888$ | in & (a) $1550-1888$ | in \\
\hline & underproduction & underproduction & underproduction \\
\hline & (b) 1889-1939 | very high & (b) 1889-1939 | very high & (b) 1889-1939 | very high \\
\hline & (c) 1940-1969 | in erosion & (c) 1940-1969 | in erosion & (c) 1940-1969 | in erosion \\
\hline & (d) 1970-2020 | contracting & (d) 1970-2020 | contracting & (d) 1970-2020 | contracting \\
\hline & $\&$ & $\&$ & $\&$ \\
\hline & (e) diachronic I in conjuncture & (e) diachronic | in conjuncture & (e) diachronic | in conjuncture \\
\hline
\end{tabular}


\& Viganò, 2018): water, railway, roads, paths, electricity network, herding areas and routes, harbours and shipping routes; geology, orography, vegetation, housing buildings, other public facilities, production buildings, plots and land use. Later, these layers are studied in their multitude of existing and potential connections both geographically, at the multi-scalar (i.e., varying between the settlement and region, and in relation to the national, and global) and historically, along multiple timeframes (identifying historical time thresholds, past and present dynamics and flows, as well as including the future short and long-term visions).

The second gaze, the inter-scalar (2), crosses scales. Extremely sparsely populated regions require with an even greater need to be understood multi-scalarly, to simultaneously grasp the complexity of spatial forces. This analysis is performed at different scales: (1) plot, scale $1: 2,500$ with attention to the form of the plot, the materiality of the architectural artefact, and its land-use variations; (2) settlement, scale 1:5,000 looking at the socionature morphologies (plot, housing, production facilities, pits, shafts, tailings, underground galleries, paths, roads, railway and water); (3) region, scale 1:500,000 (the river, railway, reindeer herding areas, herding paths, mines, settlements, harbours, seaways, military zones, plots, paths, hydropower plants, electricity lines, wind parks, data centres, cableways, fibre cable); and (4) national and (5) global interconnectedness, scales 1:10,000,000 and 1:20,000,000 (tracing the circulation of iron ore export flows, from the sites of appropriation and linked harbours to the global markets).

The chronological gaze (3) looks through time by selecting different 'time thresholds.' The periods are identified by each of the creative-destruction historical moments when the ecological surplus tendency changed and the major re-inscriptions and transformations occurred: (a) 1550-1888, in underproduction, when the structures preceding the appropriation of unpaid work/energy for capitalist accumulation were being put in place; (b) 1888-1939, very high, marking the beginning of the rapid transformation and growth until the irruption of WWII; (c) 1940-1970, eroding, during the turning post-war period of rapid expansion, spurred by added technological advancement; (d) 1971-2020, contracting, in the stagnation and shifting of the financialization of the economy; and (e) the future in conjuncture, when the tendency towards underproduction reasserts itself.

These time thresholds build up a synchronical visualisation-comparing two periods at a timedistinguishing the elements that can be qualified as permanent, persistent, transitioning or disappeared. Permanent, for when the element stays invariable in the same position, shape and dimension. Persistent, for elements that have slightly changed while keeping the same position on the ground. Transitioning, for those elements that have been moved to a new position but are keeping their shape and dimension, accepting that minor changes can be encountered. Disappeared ele- ments, for those no longer there. At the end of the successive comparisons, a final interpretation of each scale provides a diachronic image that directly reveals the historical traces still in place as well as those that are hidden from view.

\subsection{The Malm Territory Palimpsest of Appropriation}

The Malm territory provides a unique site for discussions on mapping the territory as a palimpsest of appropriation.' It has long been the object of historical investigations and subject of critical analysis (Forsgren, 1995; Forsström, 1973a, 1973b; Hansson, 1994, 1998, 2015; Luciani \& Sjöholm, 2018; Müller \& Engström, 2018; Öhman, 2016, 2020; Rizzo \& Sordi, 2020; Tidholm, 2014; Viklund, 2015) while the cartographic representation of spatial transformations has largely been ignored. It stretches from the iron ore production in the mining towns of Kiruna, Svappavaara and Malmberget, its distribution with the Malmbanan railway to the shipping harbours - Luleå by the Baltic Sea in Sweden and Narvik in Norway to the Arctic Sea-the military town of Boden to protect from foreign threats, and the hydropower plants and associated temporary towns along the Lule River.

However, the railway and mines period is merely one of several periods in which the Malm territory palimpsest was re-inscribed by stratified socio-nature appropriations. To critically understand its formation, it is necessary to trace the historical transformations and creativedestruction moments since the mid-1500s - a period where the structures for capitalist accumulation started to emerge and landscape changes occurred in a radical shift of scale, speed and scope (Moore, 2017), coinciding with the appearance of the first mappings of the northern areas, the charting of its resources by southern powers (ruling kingdoms and expanding states) and the following expropriation of the lands from Sami indigenous peoples (Elenius, Tjelmeland, Lähteenmäki, \& Golubev, 2015). To make it very clear, although the article critically focuses on the appropriation processes inherent to the unevenness of capitalist' urbanization and its ecological crisis, it is critical to stress its roots.

For 11,000 thousand years Sami indigenous peoples have lived across all of Fennoscandia-today's Sweden, Norway, Finland and eastern Russia-and its history has been violently overridden by colonial narratives, even if forming a far more advanced civilisation than what has previously been understood. New research has revealed that Sami had been producing iron and steel on an advanced large scale, 2,000 years before the Swedish colonial state and LKAB began operating (Bennerhag, 2017). This is certainly no terra nullius, and there is no frontier (Belanger, 2016). The Malm territory palimpsest of appropriation as here discussed has only been possible by the expropriation process created by the capital relation, in essence, what primitive accumulation is about. Separating indigenous peoples and settlers from the means that allow them to be self-sufficient and 
submitting them to being governed, or otherwise-if not giving up to this control-condemned to disappear (Arboleda, 2020; Öhman, 2020). Since Gustav Vasa ascended to the throne in the 1520s-when the nation of Sweden was established-and coinciding with the Protestant Reformation of the 16th century, the efforts and structures to colonise the Sami territories started to emerge. From then onwards a dialectic between capitalization and appropriation of unpaid work and energy started to form, shaped as a combination of production and distribution, and mediated by the church, the state, and its financial and institutional systems.

\subsubsection{Production Palimpsest}

The mapping operations of the production palimpsest, for the region and settlement (hereby exemplified in the mining town of Malmberget) scales, begin by synchronically comparing two periods at a time (see Figure 2a, b, c, $d$, and Figure 3a, b, c, d). Using two colour (socio-nature) gradients-blue for the social production and red for the natural production-and moving from the darker degree for the 1550s to the lighter ones for the 2020 threshold. Appropriation takes thus different forms for each ecological crisis-or say moments of creative-destruction of differential urbanization-along with the tendency of the ecological surplus to decline.

From underproduction, Figures $2 \mathrm{a}$ and $3 \mathrm{a}$ relate to the production patterns whereby the first mines in the middle valley areas linked to few paths but many dispersed small settings and smelters along the river and towards the Baltic coast, distributed strategies yet also related to the agricultural fields cultivated by settlers and farmers near church locations, or spontaneous built-up structures-close to the scattered iron ore deposits-in relation to small-scale extraction.

Very high (Figures $2 b$ and $3 b$ ); with a rapid first expansion (many new settlements appeared) and especially on the social production side (i.e., for the major need of labour power, represented in blue gradient colours, builtup areas corresponding to the municipal towns). Growth, in turn, was made possible by the secured access to cheap energy production from hydropower (the construction of which required first permanent settlements to be built). The mining operational landscapes were created in the shape between concentrated urbanizationof first informal uncontrolled shanty towns (mapped in red) and later under the added commissioned town plans (mapped in blue); and extended urbanization - the production of nature mapped in red, taking the shape of several punctual and extensive areas of mine pits and tailings (even if known these would eventually stretch towards the underground of the planned municipal towns). The pattern logics differ in the company area (with free access to the land and the means of production), and the municipal towns (controlled and planned)-both separated by a well-defined boundary, inherent to the dynamics of primitive accumulation.
In erosion; with an overall state-driven expansion mapped in the multiplication of traces that either appear both (Figure $2 \mathrm{c}$ ) regionally-as roads to serve the forestry industry, nature reserves, airports, hydropower; and at the (Figure $3 \mathrm{c}$ ) settlement scale-mining pits multiplied and extended, centralized and newly created and separated company towns, reinvestments in densified forms with new facilities and housing buildings in municipal towns and above the known location of ore deposits (establishing and structuring relatively equitable and socially homogeneous company towns, mainly to keep the needed labour in place). Shaped under an overall increasing separation logics: between company town and municipal town areas (clearly constituted by the railway infrastructure enclosing the mine); by disappearances (the river water along the now temporary towns to build the hydropower plants, or old railways and company areas overwritten by the new municipal town centres); by transitions (as the moving buildings of the temporary river towns); or by the maximized energy production which, after the technological outbreak innovation by which electricity could travel long distances, would be distributed and consumed far away nationally and internationally). In sum, an overall up-scaled appropriation of the unpaid work/energy produced by a second nature that would in turn fuel the development of the Swedish welfare state.

In the approach of a turning point whereby the ecological surplus relation is contracting (Figures $2 \mathrm{~d}$ and $3 \mathrm{~d}$ ), capitalization is exceeding appropriation, meaning a rising labour productivity and implying an even greater increase in raw materials and energy volume per labourtime (Moore, 2015a)-clearly represented in the unprecedented dimensions that the operational landscapes take at the settlement scale, in surface and in volume. And importantly in the forced disappearance of built housing structures and public buildings-representing the internalization of spaces necessary for capital accumulation to proceed, although under increased costs caused by the land subsidence of mining operations beneath (Figure 4). The latter links with the appearance of new built-up middle areas (between municipal towns), inherent to the logics of separation but also to the simultaneous financialization-where settlements move towards a reorienting into the 'tertiary circuit' (i.e., commercial services, scientific and technological innovation; Harvey, 1985). More noticeable, at the regional scale, new enclosures related to the construction of wind parks appear underway-between the middle valley and coastal areas-and concerning the last shift towards the electrification of large-scale industries, and crucially to the more electricity-intensive data centres industry (i.e., the new regional vision strategy for a 'sustainable future'). The latter represent thus just the last step into the historically layered conflicts, unceasingly deepening, between reindeer herders or indigenous modes of life and capitalist appropriations of indigenous lands and waters with unprecedented expansions in surface and intensifications in volume, the vertical shift of the production of nature. 
Diachronically, the mapping of (Figures 2e and 3e) relate to a future ecological crisis in conjuncture. They reveal the cumulative appropriations through time whereby socio-nature transformations become ever more polarized, progressively advancing from the coast to the mid-valley areas and then in between-better rep- resented in the section tool (Figure 8). In this line, appropriation repeatedly draws socio-nature urbanization into the expanding logics of separation inherent to primitive accumulation-represented between the two colour gradients and significantly between concentrated and extended urbanization processes. This is shown in its ex-
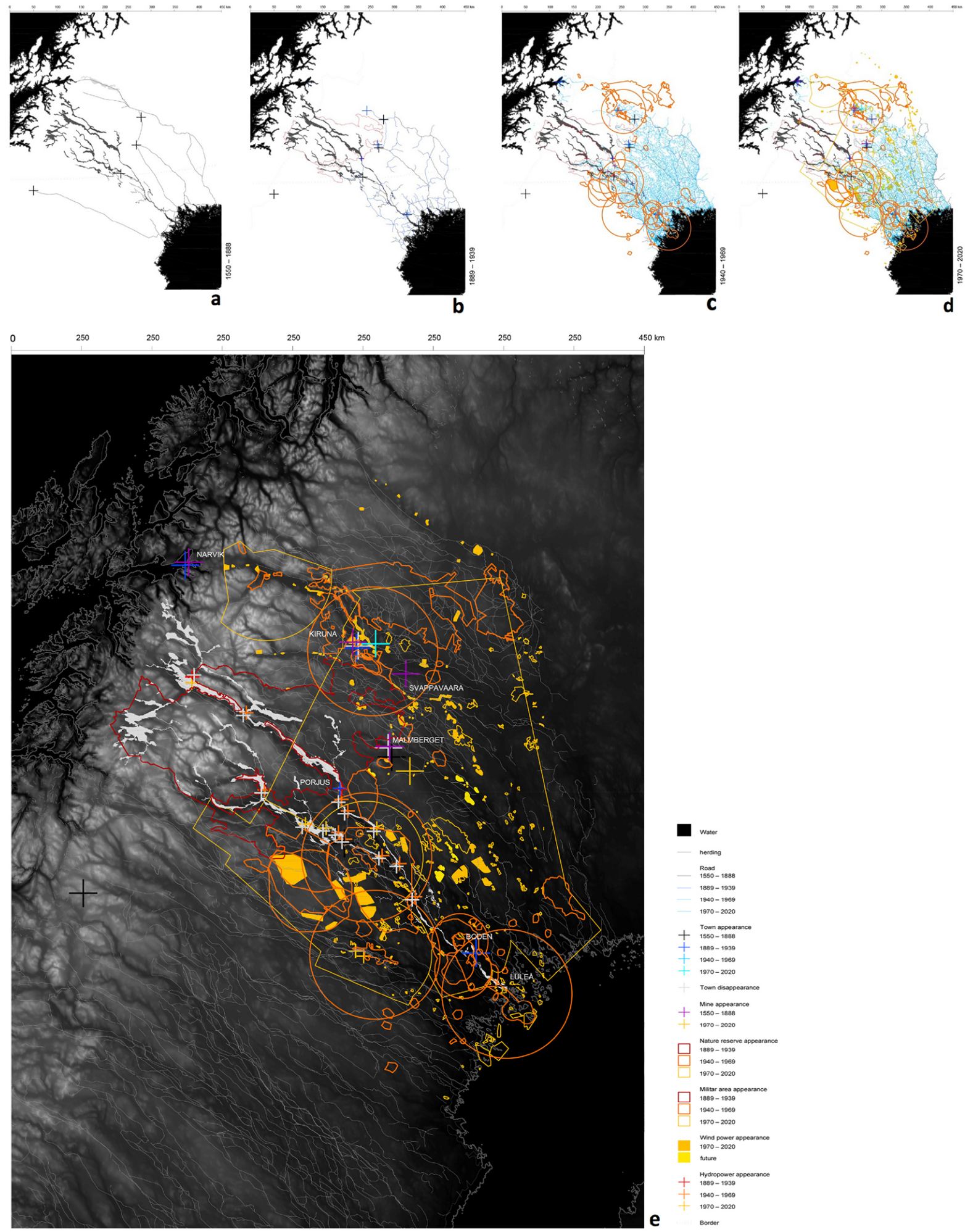

Figure 2. From images $A$ through D: Region, synchronic comparison, production palimpsest. Image E: Region diachronic production palimpsest. Source: Elaborated by Berta Morata based on Geonorge, LKAB, Natural Earth, SLU, historical maps. 
treme in the comparison as mapped in (Figures 3e, 4 and 9), with grey color for the disappeared or transient built-up areas (mainly moved buildings to the company area), and in dialectics to the expansion between pits and ore deposits. Hence, accumulation by appropriation becomes increasingly costly over time due to financializa- tion, physical depletion, and other uncertainties such as climate change or the irruption of new contesting antisystemic movements (i.e., as by the resistance and revindications of indigenous ways of life). However, intrinsic to this are also the possibilities for the remaining and hidden traces-as internalized by capitalist production-to
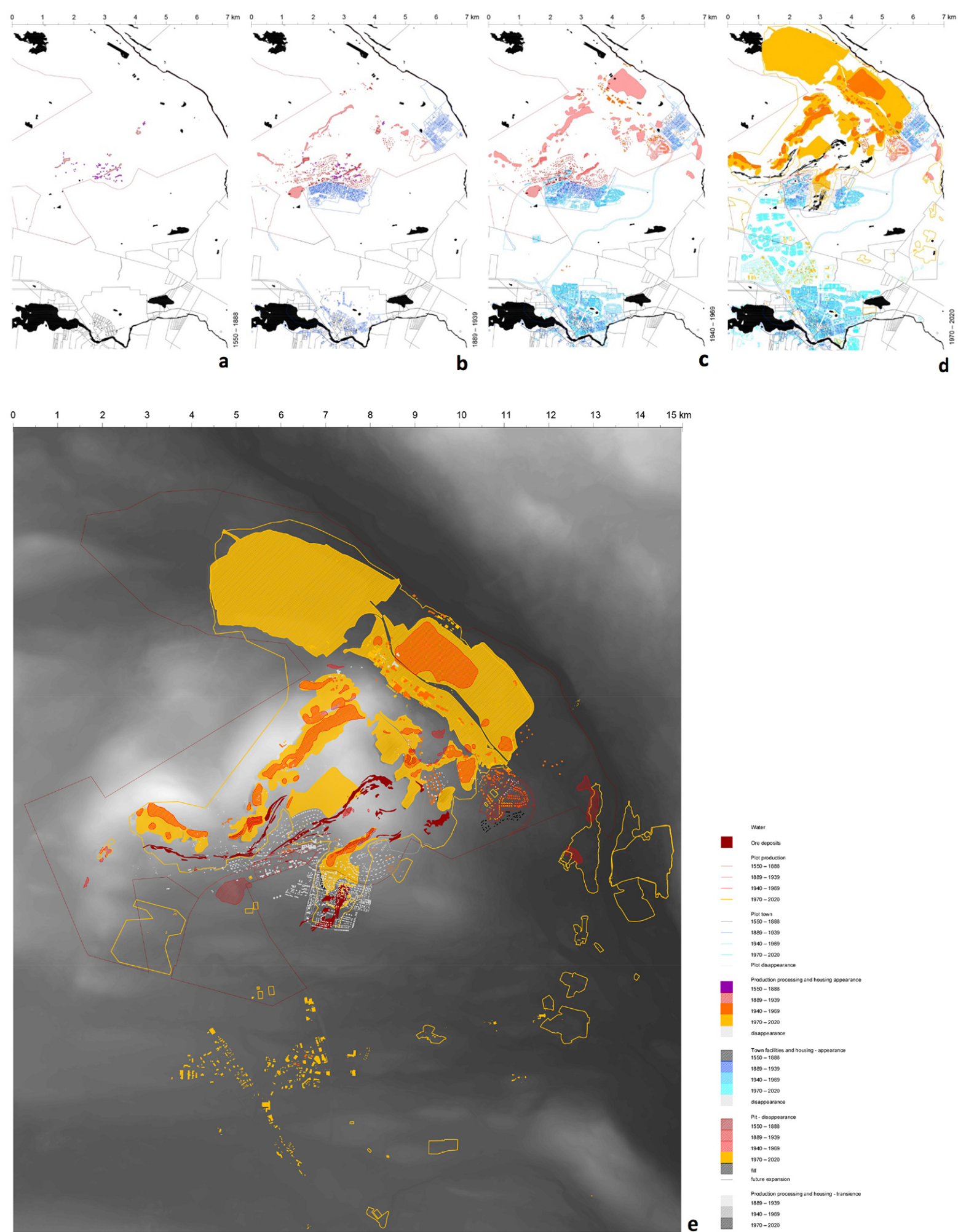

Figure 3. Images A through D: Settlement synchronic comparison, production palimpsest. Image E: Region diachronic, production palimpsest. Source: Elaborated by Berta Morata based on Geonorge, LKAB, Natural Earth, SLU, historical maps. 


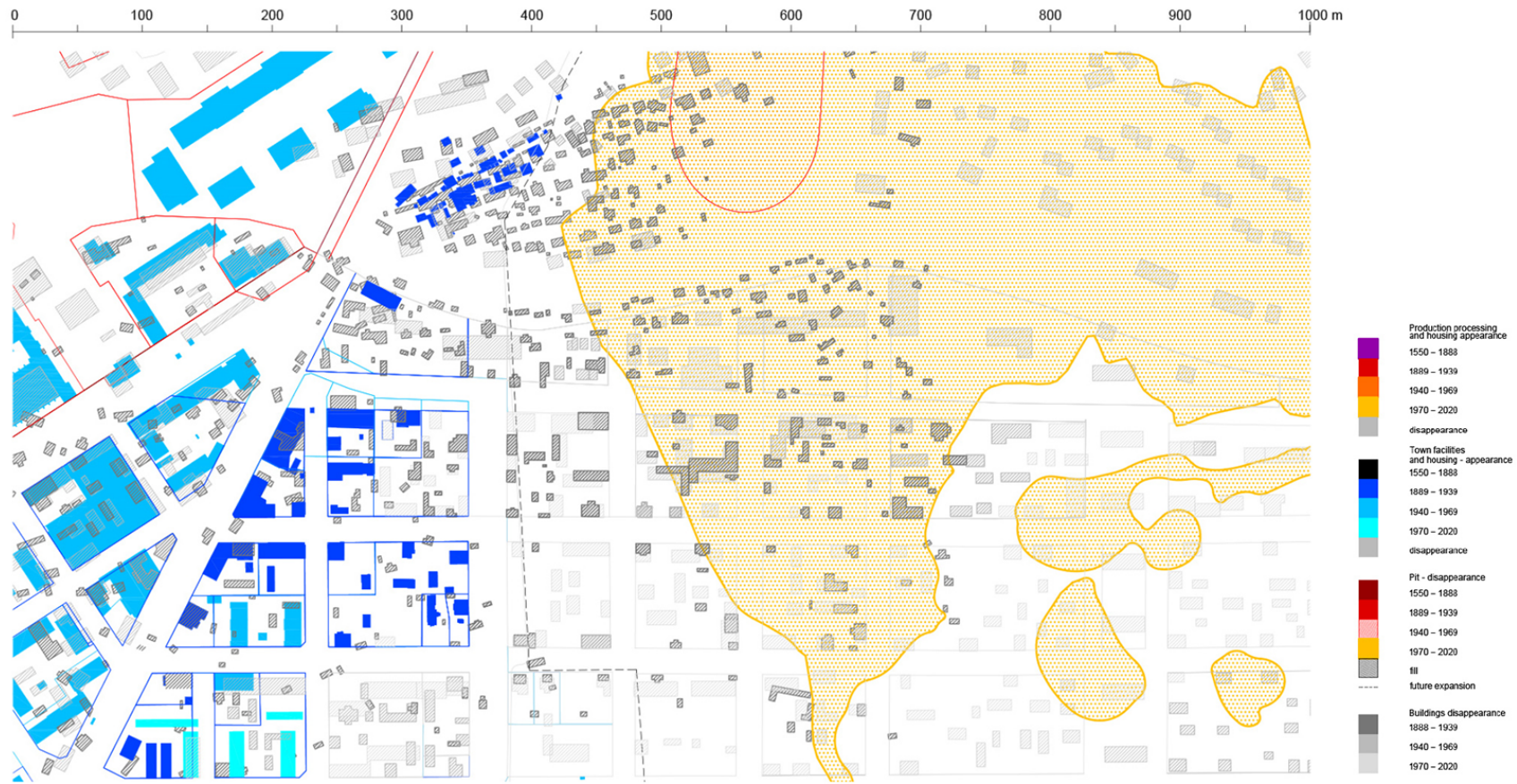

Figure 4. Plot, diachronic production palimpsest (Malmberget). Source: Elaborated by Berta Morata based on LKAB, SLU, historical maps.

be reconfigured in new ways of organizing socio-natures. These internalized spaces, through the notion of differential urbanization and commodity flows, relate to ap- propriation processes beyond the region and settlement scales (Figures 1 and 5).

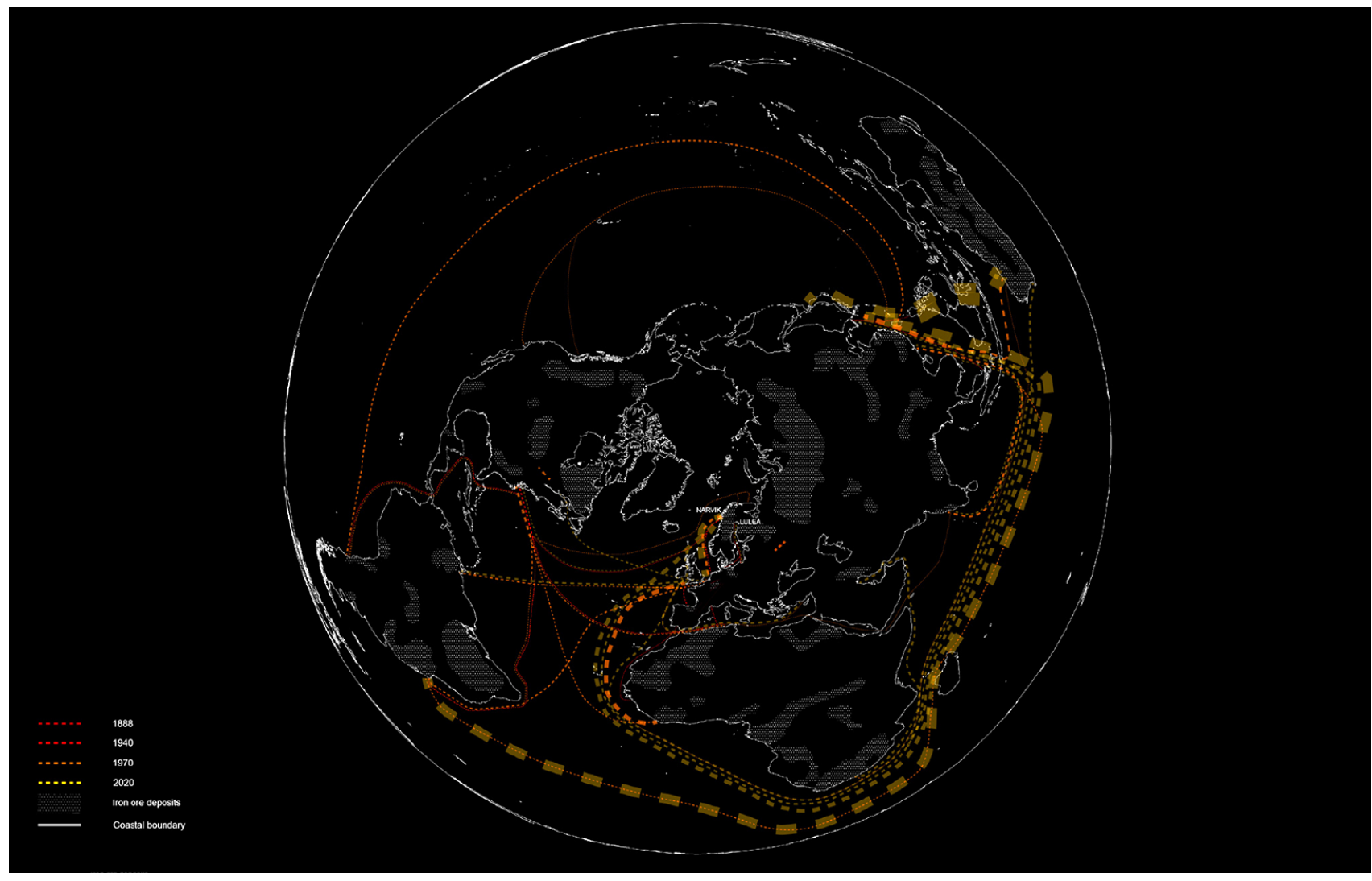

Figure 5. Global production of iron ore appropriated by the global economy. Source: Elaborated by Berta Morata, based on Natural Earth, USGS, historical maps. 


\subsubsection{Distribution Palimpsest}

The mapping of the distribution palimpsest, exemplified in (Figures 6 and 7) for the region and settlement scales, follows a similar process yet using mainly the red gradient pallet-since its traces mostly relate to the production of nature-encompassing the physical and social infrastructures that facilitate the distribution of iron ore. Hereby, capital is constantly searching to reduce the turnover time, the time that it takes to transition from the commodity form (production palimpsest) to the money form (mediation palimpsest) and returns to the capitalists as profits to be reinvested. This, in its tendency to modernize is more visibly scaling up and constantly reshaping, while rendering functioning connectivity infrastructures periodically obsolete. Yet, the constant transformations are interdependent to previous traces and to production, following different patterns and in relation to the ecological surplus tendency to fall.

From underproduction, although almost no traces appear inscribed in the map (Figures 6a and 7a), it is in this period that the most colossal attempts for distribution had been either imagined or partly built. Yet the decisive moment came with the arrival of the railway, deeply transforming the spatial and temporal logics of circulation (transporting the iron ore at higher rates). Contributing to increasing the output (from 0.02 to the $10 \%$ of the nation's total in only one year) by transporting the iron from the mining deposits of Malmberget (in the mid-valley areas) to Luleå (the coastal town by the Baltic sea), and shipped to the European markets. From that decisive moment onwards, the repeating pattern was that of first laying the path to the 'natural' site of production and then re-inscribing new traces of distribution.

Key to the next scaling-up of appropriation would be the access to more, cheaper, secured and continuous energy: hydropower; but no less important were the (thicker-mapped) electricity lines linking to the railway and mining operational landscapes. And next, the laborious and strategic extension of the railway arriving to Kiruna and Narvik (by the all-year-round ice-free Arctic sea). A period comparison (Figures $6 b$ and $7 b$ ) with a very high ecological surplus relation, where the pattern was first to link the cheap energy source to the extraction sites, and later-and only to balance overproductionelectrify the coastal settlements (mapped with thinner lines) where the majority of the population lived. This construction pattern would start to change with the irruption of air transport (and the first inner regular flight in Sweden), to build the main water reservoir in the upper-valley and remote mountainous areas. Later, and only after the Malmbanan was built, the railway link to southern Sweden (Norrastambanan) was materialized (1894), and after (1937) the next railway line crossing the mid-valley areas (Innlandsbanan). Importantly, the railway shaped the settlements in the operational landscapes beyond the mere distribution, through a pattern of enclosing mining areas in a cut-like scheme-separating the company towns from the municipal towns.

In erosion, the huge connectivity expansion drew many new inscriptions to the map (Figures $6 c$ and $7 c$ ). Technological breakthroughs are key to understanding the patterns of this post-war period, blurring boundaries in the interest of speed and connectivity. More importantly, this technological advancement meant that the expanded electricity production from hydropower in Lule River could travel great distances (linking to southern Sweden and internationally); yet also, and via its commodification, it meant the erasing of the Lule River as such (mapped in grey for disappearance). Part of the scaling-up is also the creation of airports, but so is the destruction of other infrastructures such as the Innlandsbannan railway (rapidly disappearing and never proving profitable, persisting only for summer tourism). Similar creative destruction processes occurred in the mining settlements and other hydropower sites of production, where railway trams were centralized along single trams or erased (i.e., as the mines were planning to move underground, or as some trams had only been needed for short-term construction works).

Contracting, not many new traces appear as in the previous comparison (Figures $6 \mathrm{~d}$ and $7 \mathrm{~d}$ ). Yet there is a transformation in distribution becoming faster, capitalized or perhaps more socio-intensive. With financialization, the vertical integration of nature and the irruption of new economic sectors, people, and not only the iron ore (while there are twenty iron ore trains moving between Kiruna and Narvik every day, four trains and only one a day in winter are for passengers) are moving with increased frequency by air transport-a new pattern tendency directly linked to the technological upgrading in the mining industry, requiring more and more the overspecialization of intellectual fly-in fly-out workers. On the other hand, this leads to deskilling and labour uncertainty among industrial and manual operators living in the region-for which infrastructure building is not-and has never been-prioritized. Also, on the side of appropriation of unpaid energy, the capacity of the electricity grid has been upgraded (concerning more efficient hydropower plants and maximizing production). A more interesting shift is that nowadays the energy transition is pushing toward a new-uneven-overproduction cycle in the north, in both Sweden and Norway's renewables production and distribution (IVA Electricity Crossroads project, 2017). On the one hand, this links to the push for electrifying the mining sector (i.e., mines and SSAB's smelter in Luleå); on the other, to the possibility to appropriate new lands and even sea waters for resource extraction (i.e., especially the new $420 \mathrm{kV}$ power lines linking the Lule River from Norway and arriving at the northernmost east coast and even later linking to Svalbard).

Diachronically-also represented for the national and global scales-Figures $1,5,6 \mathrm{e}$ and $7 \mathrm{e}$ relate to a future ecological crisis in conjuncture, of accumulated creative-destructions mapped in each of the successive 

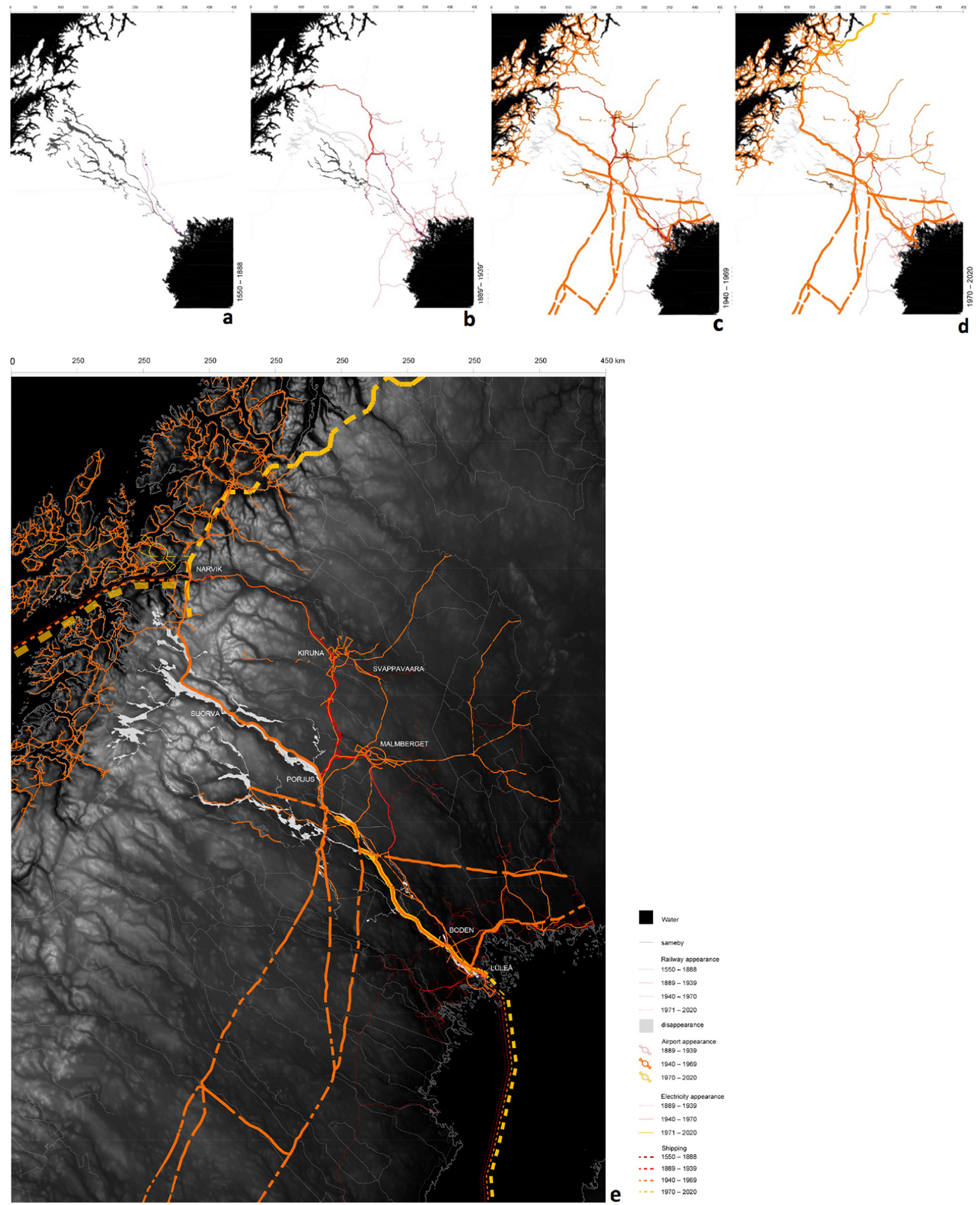

Figure 6. Images A through D: Region synchronic comparison, distribution palimpsest. Image E: Region diachronic, distribution palimpsest. Source: elaborated by Berta Morata based on Geonorge, LKAB, Natural Earth, SLU, historical maps.

appearances and disappearances. Waste and obsolete infrastructures, but also functioning or reusable ones that are internalized as left-over spaces. Hence, as the turnover times of capital continuously seek renewed up-scaling on the national and global levels (i.e., as for Sweden's next construction of the coastal railway 'Norrbotniabanan'), struggles continue to reassert at the regional and settlements scales, becoming ever more costly to overcome-beginning in turn to fetter the accumulation process. 

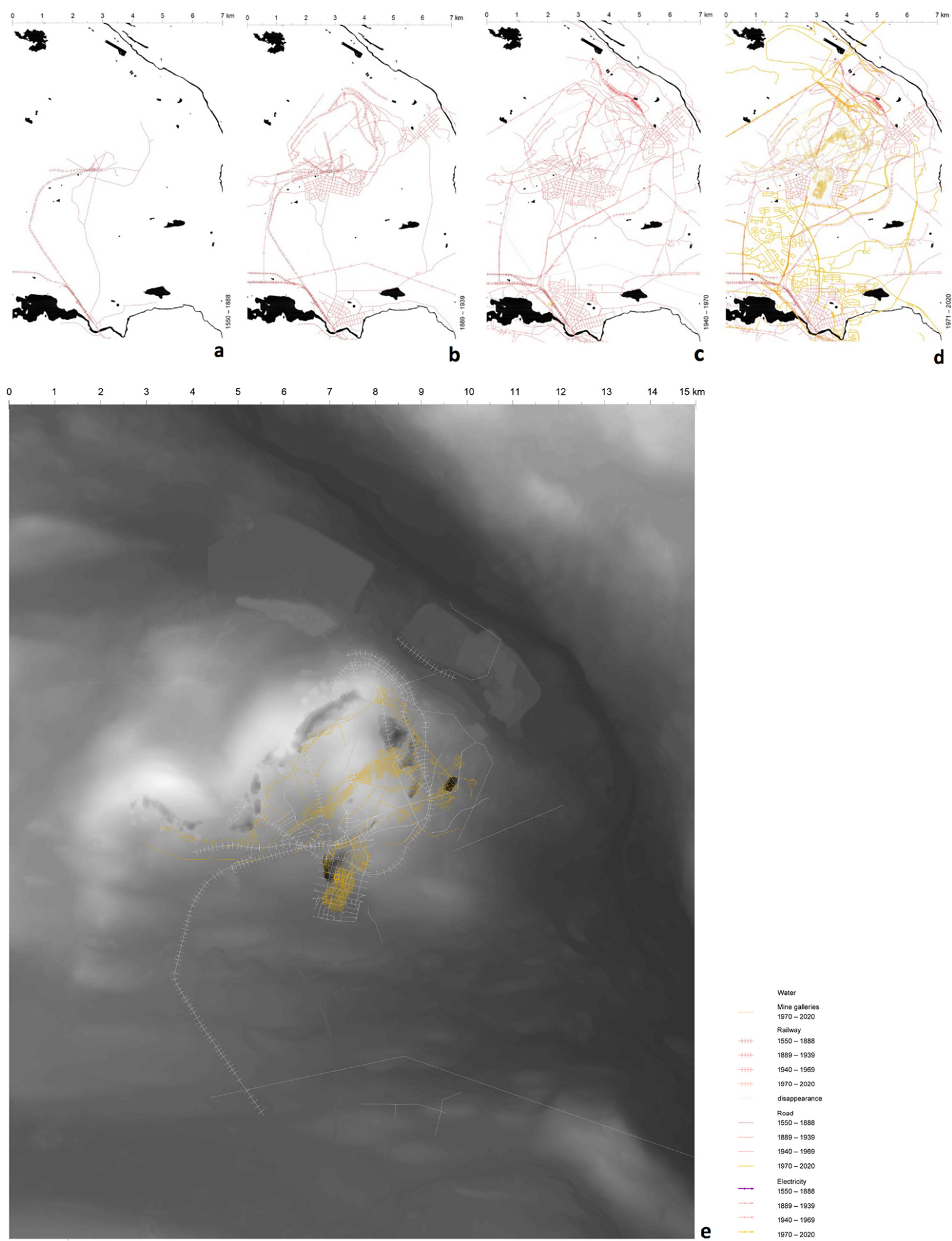

Figure 7. Images A through D: Settlement synchronic comparison, infrastructure palimpsest. Image E: Settlement diachronic, distribution palimpsest. Source: elaborated by author 1 from LKAB, SLU, historical maps.

\subsubsection{Mediation Palimpsest}

This last frame mediates the combined movement between the production and distribution frames. It manages the contradictions through the extension of credit, providing the required conditions-not spatially in a direct manner but influencing in its configurations-to the necessary appropriation in advance of real accumulation. As such, its representation does not materialize in a new set of drawings, but in an operation of interpreta- 
tion (or abstract overlapping) that consists in combining the diachronic production and distribution palimpsestconceptually and using the section tool (Figures 8 and 9). It aims to disentangle a few of the key historical facts and conditions (from texts concerning the mapping)-put in place by financial actors and institutions, policy frameworks, etc. - that produced the moments of creativedestruction which successively (re)shaped differential urbanization in each ecological crises.

Key to the formation of the Malm territory are all processes of expropriation from 1550-1888. In line with a view seeking to reveal the revolutionary shifts of environment-making - and the creation of appropriation structures - that occurred in early capitalism, and refusing the commonly accepted assumption that capitalism begins around the 1800s (Moore, 2015b). The first expropriation and colonization attempts of Sami territories could be traced back to as early as the late 13th century by the nobility and the Catholic church, yet progressively becoming more real and especially from the Protestant Reformation of the 16th century. In the 17th century, mining prospects and specific rules for settlements began shaping the Malm territory project, along with several policy frameworks such as the Lappmark Proclamation of 1673, the 1751 ratification of the Swedish-Norwegian border (whereby the reindeer feeding areas became regulated through taxes), the Avvttringen campaigns (parcelling land stolen from the Sami for the crown and settlers), the 19th century Reindeer Husbandry Acts, the development limits set by the parliament in 1867 and then breached by the government, the Nomad Schools in the 20th century (with learning restrictions for Sami children)-all contributing to the formation of the Malm territory and future successive waves of accumulation by appropriation (Öhman,
2020). Later on, the Swedish Companies Act of 1848 opened up a new way of finding domestic and foreign investors. Between 1860 and 1889 came the speculation and pouring of English capital and, in 1882, the government granted permission for the construction of the railway between Luleå and Malmberget. Throughout this colonization process, it has to be explicitly acknowledged that the Sami People owned the lands and waters, and the Swedish state expropriated or stole them under colonial and scientific racism (Lundmark, 2008)-conflicts to be framed as intrinsic to early capitalism's crisis tendency towards underproduction.

The ecological surplus relation changed to very-high once the first tram of the railway had been built, and in connection with its construction several nationaldevelopmental growth strategies came underway. In 1898 , the decision was made to build the Ofotenbanan railway, the tram to Kiruna and Narvik. In 1889, the State took over the ore fields (including the railway, Luleå's harbour and surrounding infrastructure), and the mining rights were transferred to Swedish hands. Soon after, the decision to build the fortress in Boden was made to strengthen the defence of the railways and mines. In 1907 the state became half-owner in LKAB - with the agreement for a significant increase in ore mining and transport. Such an expansion put pressure on the energy component and in 1910 the Swedish state commissioned Porjus, with the vision that electricity could grow a major development block in the north-in line with the industrial policy aiming at promoting Swedish industrial development and thereby increasing the use of domestic natural resources. A cumulus of policies that had led to an ever-increasing government involvement in different areas, designed with no cooperation and by actors without anchoring in the county (Hansson, 1998).

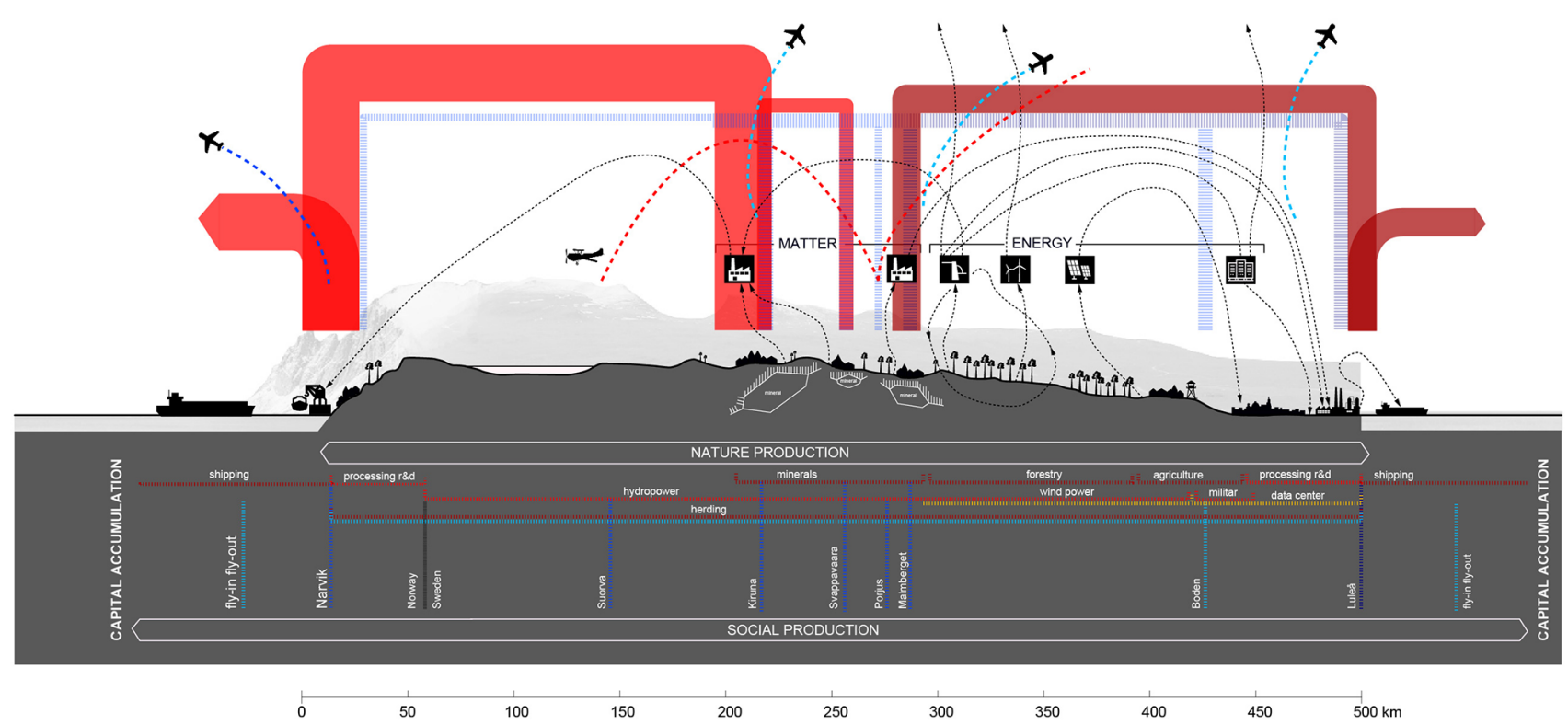

Figure 8. Region, valley section of appropriation. Source: Elaborated by Berta Morata based on Geonorge, LKAB, Natural Earth, SLU, historical maps. 


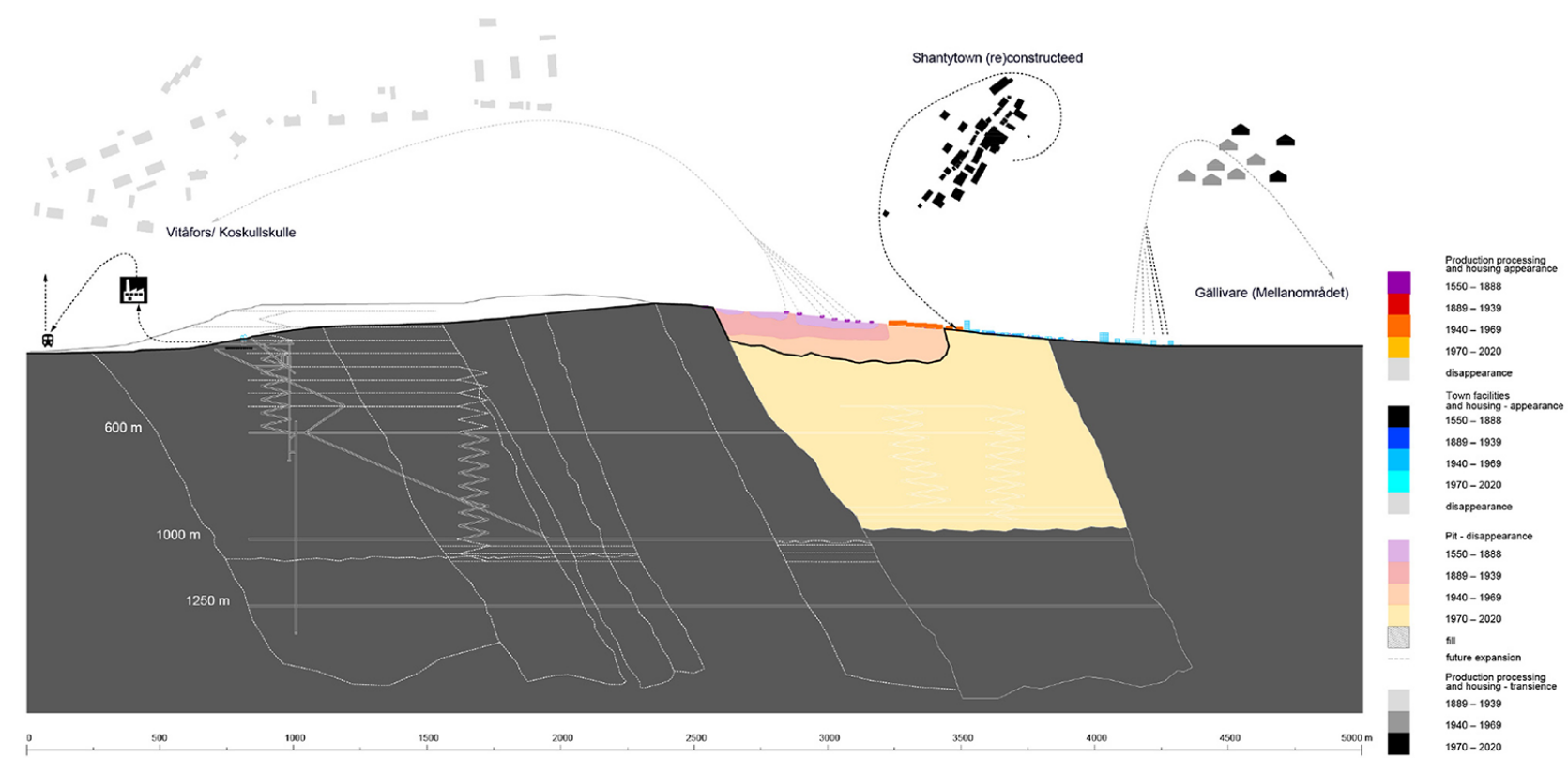

Figure 9. Settlement section (Gällivare-Malmberget-Koskullskulle). Source: Elaborated by Berta Morata based on SLU, historical maps.

The post-war period comparison, in erosion, saw a steady increase in state intervention coinciding with the growing need for labour and investment in society. It is in this line that the utopic modern projects for the mining towns are to be understood (i.e., Erskine's projects in Kiruna and Svappavaara), equally signalling the dependence of the salaried workers upon state investments and control. More extreme and ephemeral was the case for the temporary towns moving along the hydropower plant constructions in the Lule River, where housing rights were only given to employees (mostly male, discouraged to have a family or settle there). Nevertheless, such movable communities were provided with the most modern housing comforts (electricity, heating, water, plumbing, public facilities or sports fields). Even further, other creative-destruction processes were already popping up, such as from the side of the public energy company Vattenfall, which although once allied with manifold cooperatives in the process of electrification of the country, it had started absorbing the majority of them.

Contracting, the 1971-2020 comparison has more recently seen the conversion of both LKAB and Vattenfall $A B$ into privately-owned-by-the-state-companies. Along these lines, the mining industry is becoming more capitalintensive, technologically advanced and autonomous. The research and development-with a clear focus on technological innovation-conducted since 1971 in Luleå University of Technology responded to that shift. In parallel, there is a decisive reorientation of the extractive industries towards corporate and speculative behaviours. In a time of growing environmental concern, mines in Sweden are still considered so important that protection agencies allow large emissions beyond what would be tolerated in other industries (Malmberg \& Buckland,
2015). Swedish law is benefiting mining corporations and attracting foreign companies to the Swedish mining market. The legislation even allows mining companies to prospect and begin excavation on private land without the landowner's consent. The mining industry's socalled national interest trumps other socio-nature processes, but especially Sami reindeer herding and culture. Exemplification of this is that the mining industry is exempt from the landfill tax, has a lower energy tax, and only pays the mineral charge on $0,2 \%$ of the excavated value of its minerals (Tidholm, 2013). Furthermore, with China's growth decisively influencing the rise of global iron ore prices in the early 2000s LKAB decided to continue mining, even bearing with the growing costs associated with the 'move' (or building anew) of the sinking mining settlements of Kiruna and Malmberget. However, more public policies continue to be tailored to serve the next wave of accumulation underway, the establishment of data centres (i.e., Facebook from 2011), lowering taxes (by $97 \%$ in only one year) or providing for tailored urban planning even occupying former nature reserve lands (Sweco, 2017).

Still, beyond and stemming from the diachronic mapping of the mediation palimpsest, it is (among other dynamics) the underlying anti-systemic movement and resistance of Sami that is more recently revealing - behind appropriation processes and amidst the turning tendency towards underproduction. In January 2020, the Swedish Supreme Court ruled in favour of Girjas Sameby. The Sami-and not the Swedish State-will be entitled to manage the hunting and fishing rights (lost in 1993), in the continuing struggle to control their land. A historical decision completely altering the Sami's relation towards the colonising Swedish state, whereby perhaps Sami per- 
spectives could start to become guiding principles (Allard \& Brännström, 2020; Öhman, 2020).

\section{Conclusion}

This article addresses the mapping of palimpsests as a mapping of appropriation dynamics in extraction territories. More specifically, by framing the palimpsest of appropriation as a process of extraction in terms of the three intertwined frames-production, distribution, mediation - we intended to contribute to the exploration of new modes of representation of historical socionatures within the analytical framework of planetary urbanization, UPE and world-ecology.

In this sense, via the 'Malm territory,' this work discloses an expanded notion of palimpsest, one that goes beyond the mere morphological analysis of sites, beyond the traditional scalar understanding of the urban and beyond the national notion of city and territory production. More particularly, this article clarifies (1) how uneven spatial developments developed over time; (2) how synchronic maps highlight those processes of appropriation that have constantly (re)made socio-natures throughout historical creative-destruction thresholds - that is to say throughout waves of imperialist capital accumulationand, as a consequence; (3) how diachronic maps highlights how the disappearing-but yet accumulatedsocio-natures can be either (re)appropriated or otherwise be left fallow as signs of precedent overaccumulation; we also looked into (4) how chronological analyses can break down those contradictions of scale, economy and processes that are embedded in the regions of extended urbanisation and, ultimately; (5) how space, within these processes, unprecedentedly extended both in surface and in volume.

The power of the visualization of the proposed palimpsest of appropriation may thus lie in the possibility and capacities to resist and destabilise the map as mere political technology-especially with its focus on the plot, settlement and regional scales-yet simultaneously morphologically relating to the intertwined production of socio-natures. By relating between the different forms extraction takes in each of the frames, this methodology has allowed to better understand the link and relevance of the production of nature as a very important part of urbanization and concerning the main agglomerated landscapes. As displayed here but, the historical and multi-scalar (beyond the more in focus discussed region and settlement scales) differential urbanization of extraction remains unexplored-and so, the appropriation process that continue beyond the actual sites of extraction.

Thus, and beyond the aim and space of this article, as production is not only natural but also social (socionatures), the appropriation in remote territories of extraction should indeed be the object for the project of radically reorganizing urbanization as 'socio-natures production'-and not merely of distribution of, say 'death' or 'passive nature' from 'elsewhere.' Questioning the articulation between socio-nature processes of separation (or appropriation relations) would be at its centre.

\section{Acknowledgments}

This article has greatly benefited from feedback received at the PhD seminar "Habitats in Time," from comments and constructive criticism by Janike Kampevold, Hannes Zander, Sofia Löfgren, David Chapman, Peter Hemmersam, and the three anonymous reviewers at Urban Planning. In addition to this, the authors would like to thank the editors of this thematic issue for their feedback. The researchers at LTU would like to acknowledge funding from Formas for the project "Ecodistricts" 2018-01267 (LPI: Agatino Rizzo). The usual disclaimers apply.

\section{Conflict of Interests}

The authors declare no conflict of interests.

\section{References}

Allard, C., \& Brännström, M. (2020). Girjas sameby mot staten: En analys av Girjasdomen [Girjas Sami Village against the State: An Analysis of the Girjas Judgment]. Svensk Juristtidning, 429-452.

Angelo, H., \& Wachsmuth, D. (2015). Urbanizing urban political ecology: A critique of methodological cityism. International Journal of Urban and Regional Research, 39(1), 16-27.

Arboleda, M. (2016). In the nature of the non-city: Expanded infrastructural networks and the political ecology of planetary urbanisation. Antipode, 48(2), 233-251.

Arboleda, M. (2019). From spaces to circuits of extraction: Value in process and the mine/city nexus. Capitalism Nature Socialism. Advance online publication.

Arboleda, M. (2020). Planetary mine: Territories of extraction under late capitalism. Brooklyn, NY: Verso Books.

Belanger, P. (2016). Extraction: Canadian exhibition at the 2016 Venice biennale. ARQ, 2016(93), 124-131.

Bélanger, P., \& Lister, P. N. E. (2018). Extraction empire: Undermining the systems, states, and scales of Canada's global resource empire, 2017-1217. Cambridge, MA: MIT Press.

Bhatia, N., \& Casper, M. (2013). The petropolis of tomorrow. Barcelona: Actar Publishers.

Brenner, N. (2019). New urban spaces: Urban theory and the scale question. New York, NY: Oxford University Press.

Brenner, N., \& Katsikis, N. (2020). Operational landscapes: Hinterlands of the capitalocene. Architectural Design, 90(1), 22-31.

Brenner, N., \& Schmid, C. (2015). Towards a new epistemology of the urban? City, 19(2/3), 151-182.

Brenner, N., Goh, K., Gomez-Luque, M., Ibañez, D., Katsikis, N., \& UTL Students. (2013). Operational land- 
scapes: Towards an alternative cartography of world urbanization. Cambridge, MA: Urban Theory Lab.

Bennerhag, C. (2017) Järn $i$ Norr [Iron in the North; Video file]. Retrieved from https://www.youtube. com/watch?V=05QQshzKQPU

Cavalieri, C., \& Viganò, P. (2018). Horizontal metropolis: A radical project. Zurich: PARK Books.

Corboz, A. (1983). Le territoire comme palimpseste [The land as palimpsest]. Diogène, 121, 12-31.

Correa, F. (2016). Beyond the city: Resource extraction urbanism in South America (1st ed.). Austin, TX: University of Texas Press.

Elden, S. (2015, November 13). Territory: Political technology, volume, terrain [Video file]. Retrieved from https://www.youtube.com/watch?v=-QiS714BXxc

Elden, S. (2019). Territory/territoriality. In A. M. Orum (Ed.), The Wiley Blackwell encyclopedia of urban and regional studies (pp. 1-11). Atlanta, GA: American Cancer Society.

Elenius, L., Tjelmeland, H., Lähteenmäki, M., \& Golubev, A. (2015). The Barents region: A transnational history of subarctic Northern Europe. Oslo: Pax forlag.

Forsgren, N. (1995). Harsprånget: Storverket som aldrig höll på att bli av [Harsprånget: The big deal that never got rid of]. Porjus: Porjus arkivkommite.

Forsström, G. (1973a). Gällivare: tatört och landsbygd [Gällivare: Urban and rural areas]. Luleå: Norrbottens Museum.

Forsström, G. (1973b). Malmberget: Malmbrytning och bebyggelse [Malmberget: Ore mining and settlement]. Luleå: Norrbottens Museum.

Gago, V., \& Mezzadra, S. (2017). A critique of the extractive operations of capital: Toward an expanded concept of extractivism. Rethinking Marxism, 29(4), 574-591.

Genève République et Canton. (1993). Atlas du territoire genevois: Permanences et modifications cadastrales aux XIXe et XXe siècles [Atlas of Geneva territory: Permanences and cadastral changes in the 19th and 20th centuries]. EPFL Scientific Publications. Retrieved from http://infoscience.epfl.ch/ record/51586

Hansson, S. (1994). Porjus: En vision för industriell utveckling i övre Norrland [Porjus: A vision for industrial development in upper Norrland]. Luleå: Luleå University of Technology.

Hansson, S. (1998). Malm, räls och elektricitet: Skapandet av ett teknologiskt megasystem i Norrbotten 1880-1920 [Ore, rail and electricity: Creation of a technological megasystem in Norrbotten]. In Den Konstruerade Världen [The constructed world]. Eslöv: B. Östlings bokförl. Symposium.

Hansson, S. (2015). Malmens land: Gruvnäringen i Norrbotten under 400 år [The ore's land: The mining industry in Norrbotten for 400 years]. Luleå: Tornedalica.

Harvey, D. (1985). The urbanization of capital. In The urban experience (pp. 17-58). Baltimore, MD: Johns Hopkins University Press.
Harvey, D. (1989). The urban experience. Baltimore, MD: Johns Hopkins University Press.

IVA Electricity Crossroads project. (2017). Sweden's future electrical grid. A project report. Retrieved from https://www.iva.se/en/published/swedensfuture-electrical-grid--a-project-report

Katsikis, N., \& Ibañez, D. (Eds.). (2014). New geographies 06: Grounding metabolism. Cambridge, MA: Harvard Graduate School of Design.

Katsikis, N. (2016). From hinterland to hinterglobe: Urbanization as geographical organization (Doctoral dissertation). Harvard GSD, Cambridge, USA.

Khan, D., \& Karak, A. (2018). Urban development by dispossession: Planetary urbanization and primitive accumulation. Studies in Political Economy, 99(3), 307-330.

Länsstyrelsen Norrbotten. (2018). Formellt skyddad skog $i$ Norrbottens län [Formally protected forest in the Norrbotten County]. Retrieved from https:// www.lansstyrelsen.se/download/18.6ae610001636 c9c68e537bb2/1529581855002/2018_Rapport_ Formellt_skyddad_skog_i_Norrbottens_län.pdf

Layne, M. K. (2014). The textual ecology of the palimpsest environmental entanglement of present and past. Aisthesis: Pratiche, 7(2), 63-72.

Lefebvre, H. (1970). La révolution urbaine [The urban revolution]. Paris: Gallimard.

LKAB. (2013). Integrated report: Annual and sustainability report 2012. Luleå: LKAB. Retrieved from https:// www.lkab.com/en/SysSiteAssets/documents/ finansiell-information/en/annual-reports/ Ikab_2012_annual_and-sustainability_report.pdf

Luciani, A., \& Sjöholm, J. (2018). Norrbotten's technological megasystem as a heritage discourse: Paradoxes and controversies. In AMPS Proceedings (pp. 292-300). London: Amps.

Lundmark, L. (2008). Stulet land: Svensk makt påsamisk mark [Stolen land: Swedish power in Sami land]. Stockholm: Ordfront.

Malmberg, J., \& Buckland, J. (2015). The Norrbotten technological megasystem. Impact on society and environment. Retrieved from https://jbuckland.com/ assets/pdfs/norrbotten.pdf

Marx, K., \& Mandel, E. (1976). Capital: A critique of political economy. Vol. 1 (Repr.). Harmondsworth: Penguin.

Marx, K., \& Mandel, E. (1992). Capital: A critique of political economy (Vol. 2). Harmondsworth: Penguin.

Marx, K., \& Nicolaus, M. (1993). Grundrisse: Foundations of the critique of political economy. London: Penguin.

Mezzadra, S., \& Neilson, B. (2013). Extraction, logistics, finance: Global crisis and the politics of operations. Radical Philosophy, 178, 8-18.

Mezzadra, S., \& Neilson, B. (2017). On the multiple frontiers of extraction: Excavating contemporary capitalism. Cultural Studies, 31(2/3).

Moore, J. W. (2015a). Capitalism in the web of life: Ecology and the accumulation of capital (1st ed.). New 
York, NY: Verso.

Moore, J. W. (2015b). Nature in the limits to capital (and vice versa). Radical Philosophy, 193(September/October), 9-19.

Moore, J. W. (2016, January 5) Political ecology or world ecology? [Video file]. Retrieved from https:// www.youtube.com/watch?v=-fwaw51S9gs\& feature=emb_title

Moore, J. W. (2017). The capitalocene, Part I: On the nature and origins of our ecological crisis. Journal of Peasant Studies, 44(3).

Moore, J. W. (2018). The capitalocene, Part II: Accumulation by appropriation and the centrality of unpaid work/energy. Journal of Peasant Studies, 45(2).

Müller, A., \& Engström, M. (2018). Norrlandsparadoxen: En utvecklingsdröm med problem [Northern Sweden paradoxes: A developmental dream with problems]. Johanneshov: MTM.

Öhman, M. B. (2016). Technovisions of a Sámi cyborg: Reclaiming Sámi body-, land-, and waterscapes after a century of colonial exploitations in Sábme. In J. Bull \& M. Fahlgren (Eds.), Illdisciplined gender: Engaging questions of nature/culture and transgressive encounters (pp. 63-98). Cham: Springer International Publishing.

Öhman, M. B. (2020). Gut la dån? Ver är du? Kukas sie olet? [Who are you? An alternative perspective on the history of the north]. In D. Golling \& C. Carrasco (Eds.), Kiruna forever (pp. 238-246). Stockholm: Arkitektur förlag.

Ponte, A., \& Kowal, S. (2017). 'Making the North': Mines and towns of the Labrador Trough. In J. Hutton (Ed.), Material culture: Assembling and disassembling landscapes (pp. 62-89). Berlin: Jovis Verlag.
Raffestin, C. (1980). Pour une géographie du pouvoir [For a geography of power]. Paris: LITEC.

Rizzo, A., \& Sordi, J. (2020). Resources and urbanization in the global periphery: Perspectives from urban and landscape studies. Cities, 100(February).

Schmid, C. (2015). Specificity and urbanization: A theoretical outlook. In The inevitable specificity of cities: Napoli, Nile Valley, Belgrade, Nairobi, Hong Kong, Canary Islands, Beirut, Casablanca... (pp. 287-305). Zürich: Lars Müller.

Smith, N. (2007). Nature as accumulation strategy. Socialist Register, 43, 16-36. Retrieved from https://socialistregister.com/index.php/srv/article/ view/5856

Smith, N. (2010). Uneven development: Nature, capital and the production of space. London: Verso.

Sordi, J., Valenzuela, L., \& Vera, F. (2017). The camp and the city: Territories of extraction. Trento: ListLab.

Sweco. (2017). Effekter av Facebooks etablering i Lulea [Effects of Facebook's establishment in Luleå]. Retrieved from http://www.mynewsdesk.com/se/ tillvaextverket/documents/rapport-effekter-avfacebooks-etablering-i-luleaa-72282

Tidholm, P. (2013, February 4). Flathet för gruvnäringen [Flatness for the mining industry]. Norrbottens Kuriren. Retrieved from https://www.kuriren. nu/nyheter/flathet-for-gruvnaringen-6733834.aspx

Tidholm, P. (2014). Norrland [Northern Sweden]. Luleå: Teg Publishing.

Tzaninis, Y., Mandler, T., Kaika, M., \& Keil, R. (2020). Moving urban political ecology beyond the 'urbanization of nature.' Progress in Human Geography.

Viklund, R. (2015). The book of LKAB: 1890-2015. Luleå: LKAB.

\section{About the Authors}

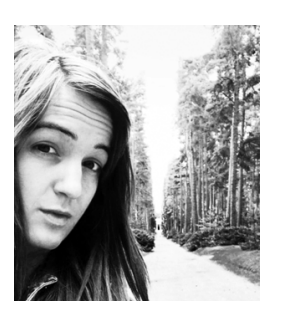

Berta Morata is an Architect graduated from the ETSAV-UPC BarcelonaTECH in 2015, and PhD student in urbanism at Luleå University of Technology since 2017. She has practiced and collaborated with several international offices. Her actual research is at the intersection of urbanization theory, geospatial analysis, design and ecology, and is primarily interested in the spatiality and representation of urbanization processes. Currently researching on territories of extraction in the European Arctic.

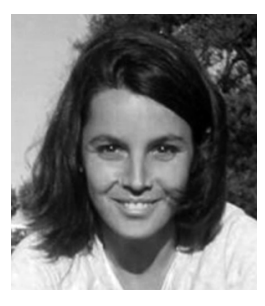

Chiara Cavalieri, Architect and PhD in Urbanism (IUAV, University of Venice), is Professor of Urbanism and Territorial Management at the Université Catholique de Louvain (UCLouvain) and member of the executive committee of the Habitat Research Center (HRC) at EPFL. Over the last years, she has taught and collaborated with a number of different international schools, including IUAV Venice, GSD Harvard, EPFLausanne, ITMO St. Petersburg, and ENSAP Lille.

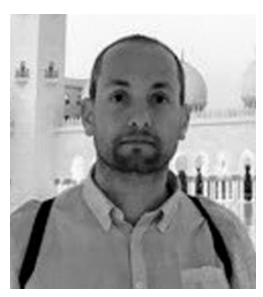

Agatino Rizzo, PhD in urban and regional planning, works as an Associate Professor and Acting Chair in the architecture research group at Luleå University of Technology. In the past years, he has been the lead principal investigator in a number of externally-funded research projects dealing with the small-scale integration of renewable energy into the built environment. 


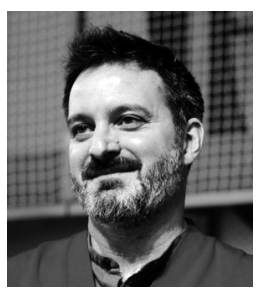

Andrea Luciani is MSc in Architecture and PhD in Preservation of Architectural Heritage (Politecnico di Milano, 2007 and 2013). His research on the sustainable management of built heritage has ranged from indoor climate and energy efficiency in historic buildings to the preservation of modern architecture. Currently Researcher at Luleå University of Technology and Research Fellow at ArkDes, he studies how resource extraction is affecting local historic mining towns. 